\title{
Economic Globalization and the Problem of Achieving Arab Economic Integration
}

\author{
Adnan Mnati Salih \\ Baghdad College of Economic Sciences University \\ adnanmsalsaadi92@gmail.com
}

\begin{abstract}
By describing economic globalization as a contemporary phenomenon that has its historical roots, mechanisms and effects on various economies in the world, especially through capital and direct investments using transcontinental companies, and the need of developing countries, including Arab ones, for these capital and investments, it becomes difficult to block the entry points of this globalization into economic projects in various World countries, including the Arab economic integration project. This integration faces internal challenges just as it faces external challenges, including the challenge of economic globalization.
\end{abstract}

The importance of the research: lies in what constitutes Arab economic integration in the process of building and developing Arab countries, as the basic material pillar of these countries, which faces many challenges, including the challenge of economic globalization.

Research problem: The Arab economic integration project is a renaissance project for the Arabs, and therefore it faces challenges that are not easy, especially the new Middle East project, which represents one of the projects that approach globalization with economic thought and mechanisms.

The aim of the research: To study the relationship between economic globalization and the issue of Arab economic integration, which represents a necessary need for the present and future of the Arab nation.

Research hypothesis: Globalization has positive and negative effects on the process of Arab economic integration, and it is difficult to bridge the gates of globalization mechanisms in this integration.

Research methodology: The research adopts the method of deductive descriptive analysis that is based on the historical method. The research will include three topics, the first is Arab economic integration - the project and challenges, the second is the concept of economic globalization and its dimensions, and the third is the effects of economic globalization on Arab economic integration.

\section{ARAB ECONOMic InTEgRAtion - Project AND CHALLENGES}

International economic integration is one of the most important areas of economic cooperation between countries, especially neighboring countries, and it represents the deepest and broadest aspect of this cooperation in the history of international economic relations. This integration has emerged since the first half of the last century, and the issue of economic integration at the state level does not differ in its study at the state level, but the first is studied more broadly because it is at the level of several countries that have their conditions and problems that differ from them in one country, and there are differences in many issues between One country and between several countries, including:

1. The possibility of movement of the elements of production, such as labor and capital.

2. The difference in value, types and forms of money.

3. Market size. (1)

4. Trade policies and internal restrictions on foreign trade

This integration takes several stages or forms according to its degrees, namely ${ }^{(2)}$ :

1. Free Trade Zone.

2. The Customs Union.

3. Economic Union.

4. Macroeconomic integration.

The experiences of economic integration between countries show that some of them were formed according to these forms and their increment represented by the integration of the European Economic Community, whose main goal was to achieve European economic unity, which was launched first from customs unification procedures, then gradually unifying economic policies to reach a common market and then the actual implementation of economic unity. The European Union, and then began a period of more expansion, economically, politically, and socially, and in equal opportunities for the peoples of this bloc. In other experiences, it did not witness these stages or gradualism, because each country or group of neighboring countries has its own economic conditions and problems. Usually, every international economic integration has goals, which may not stop at economic, but rather political, social, military and cultural goals. Countries use many means to achieve this, the most important of which are:

1. Lifting of barriers, customs duties and administrative restrictions imposed on exported goods and imported between member states.

2. Applying one common customs tariff to all member states.

3. Adopting a common commercial policy regarding exports and imports.

4. Adopting a joint agricultural, industrial and transport policy among the member states.

5. Adopting joint policies to regulate the movement of people, goods and capital between member states. 
Thus, international economic integration is a profitable economic project for the member states, in addition to its political, military, social and cultural benefits. With regard to Arab economic integration, it has been covered by many studies and research, especially since the establishment of the Arab League in 1945 until now, which was expressed in the Economic Unity Agreement concluded in 1957, and then the decision of the Arab Common Market in 1964, which was not practically realized on the ground. It expresses the failure of this integrative project. In addition, other projects have not been able to achieve their goals, for example, but not limited to the Gulf Cooperation Council project, which was established in 1981, then the Arab Cooperation Council, which was established in 1989, which became a thing of the past after Iraq's occupation of Kuwait in 1990, and the Maghreb Union in 1989. Which also did not achieve the aspirations of the mechanism of the countries of this union, and this failure was the share of these projects despite the fact that these groupings of resources and wealth make them or are transferred qualitatively in the economic life of the member states if the political wills are available, as happened in the European Common Market Agreement in life European $^{(3)}$.

It should be noted that there are internal and external obstacles and challenges that prevent the realization of this integration project, which represents an Arab national system based on the Arab cultural heritage and national feeling (4), and which collides with the Middle East project, which represents a regional system based on geographical foundations and economic interests that finds in economic integration $\mathrm{Al}$ Arabi is a strong challenge to him.

The internal obstacles and challenges are as follows:

1. The nature of the ruling political regimes in the Arab countries that approach dictatorship and their individual policies that have led to failure in any step towards this integration.

2. The difference in economic policies in the Arab countries, some of them are highly centralized in managing the economy and others are a free market economy system, which makes this contradictory and intersecting.

These policies constitute a constraint on this integration and on the rates of development ${ }^{(5)}$.

3. The difference in the size of the economic resources that these countries possess.

4. The Qatari closure of some Arab countries and the trend towards self-sufficiency ${ }^{(6)}$.

5. The large external indebtedness of most Arab countries.

As for the external obstacles and challenges, the most prominent of them are:

1. International policies, especially those of the great and major countries, and in particular the phenomenon of economic globalization.

2. The Israeli settlement expansion project at the expense of the Arabs.

3. The ambitions of foreign regional countries in some Arab countries such as Iran and Turkey, which prevent the implementation of any project that leads to strengthening
Arab national security. These challenges are intertwined in a common challenge for the Arabs, which is the Middle East project. For these internal and external reasons, the Arab project for economic integration failed. Rather, it sowed despair in the hearts of the children of Arab countries. Thus, this Arab integration was not achieved, serious independent development was not achieved in the Arab countries, the economies of these countries were not freed from foreign subordination and control, and the economic goals that the masses of the Arab nation aspired for were not achieved. The Arab countries continued to retreat in their integrative project, especially after the events of Iraq's occupation of Kuwait, and then what happened from the American invasion of Iraq and the destruction of its state, and then the so-called Arab Spring in a number of Arab countries, all of which led to the exacerbation of the Arab economic, political, military and cultural decline. Indeed, the great decline in this integration project began, and failure became the answer to this project, and hope became lost in any economic integration step after the deterioration of Arab-Arab relations in the last decade of the last century, which took the form of regional conflicts in some regions and a decline in the Arab nationalist movement in other regions.

Based on the foregoing, the integrated Arab economic system now represents the following:

1. Historically, it represents human, linguistic, religious and cultural homogeneity - Arab and Islamic.

2. Geographically, the Arab countries are located in Asia and North Africa.

3. Economically, the economic system is based on the role of the state and its public sector, along with the role of the private sector.

\section{In terms of goals, its nature is revivalist.}

This means the availability of requirements for the realization of this project. While the integrated system for the new Middle East, which represents a fundamental challenge to the Arab economic integration project, is based on the following:

1. Historically, its peoples do not share a common cultural heritage, but rather have several civilizations.

2. Human beings, heterogeneous because he has many races, religions and cultures.

3. Geographically, it is wider than the geography of the Arab world, as it includes Arab countries such as Iran and Turkey in addition to Israel (noting that Iran at the present time is inconsistent with and against this project).

4. Economically, this economic system is based on the leadership of the private sector and the free market system, and towards globalization and integration into the global capitalist economy.

5. In terms of objectives, its political nature is fragmented, nationally and nationally.

On these foundations, the two integrated Arab and Middle Eastern projects are two competitive projects, far from one another in some goals and means. Arab economic integration is an Arab national project behind which Arabs in the Arab world stand, while the horrific Middle Eastern integration is countries, some of which are opposites, and it 
is a serious challenge to the Arab economic project. Therefore, contradiction and conflict remain between them.

\section{The CONCEPT OF ECONOMIC GLOBALIZATION AND ITS DIMENSIONS}

In the year 1989, after the collapse of the Soviet Union and the socialist bloc, and the uniqueness of the United States of America as a superpower in the world, the term (globalization) became popular and emerged as a new economic phenomenon that means the freedom of markets and their integration into the world in the areas of the transfer of goods, services, capital and manpower, so that these markets become as if they were one market in a village.

This phenomenon has historical roots dating back more than five centuries, meaning with the birth of the capitalist system and the occurrence of industrial and commercial progress and the development of technology, this system sought to impose and popularize its theory (the free market economy) and reflected the will to dominate the world, in particular.

After the Second World War, through many economic conferences and international events that paved the way for this phenomenon, most notably the following:

1. The (Bretton Woods) Agreement in 1944 and its laying of the foundations for a new international monetary system in which the US dollar had an important role.

2. The General Agreement on Tariffs and Trade (GAT) in 1948 with American and Western European wording, which replaced the (World Trade Organization for Trade) as an alternative to GAT.

3. The (Davos) conference that was held in 1971 as the (European Forum), whose name was changed in the years 1987 to the (World Economic Forum) attended by representatives of many countries and private companies, and which continued to convene annually.

4. The collapse of the Soviet Union and the socialist bloc in 1989, which was the most important event in the emergence of the phenomenon of globalization.

5. The tremendous development of the information and communication system and international trade.

These conferences and events were basic preludes to the phenomenon of economic globalization, which was associated with the development and formation of economic mechanisms more capable of serving this phenomenon, and these mechanisms were manifested in the following:

1. Multinational companies (transcontinental) that were an important tool in the transmission of goods, services, capital, manpower, information and ideas ${ }^{(7)}$. It was a tool for developing international investments in many countries of the world, including socialist countries, especially China, which worked with the socialist market system, and which led to technological development and modernization that made China at the forefront of economically developed countries, yet it had negative effects such as corruption and inflation.

2. International economic organizations (financial and monetary), such as the International Monetary Fund and the World Bank, which are subject to the control of the United States by virtue of their large funding to them, which made these organizations do what serves the concepts and mechanisms of this globalization.

3. Foreign trade between the United States and other countries, including economic competition with them, such as China and Russia, by imposing restrictions contrary to free trade, such as imposing duties on Chinese goods and services entering America.

4. The use of the American dollar as a dominant tool in the phenomenon of globalization in particular. This dollar has become the leading currency in settling international payments and in pricing strategic goods.

Therefore, globalization has economic and non-economic goals, whose advocates claim to increase the volume of international trade and the rates of economic growth and provide job opportunities for the unemployed, and its opponents claim that it blurs sovereignty, interferes in countries and creates economic chaos.

Based on the foregoing, this globalization has political, cultural and social dimensions, as well as the economic dimensions, which means imposing a specific culture on the world, which is not universal, which means openness to other cultures. These dimensions are reflected as follows:

1. The role of nationalism and the political role of the state, especially its economic decision, retreated. Thus, the role of patriotism declined and the role of local government weakened to the so-called global government represented by economic globalization in the processes of economic development, technological progress and the issue of social justice.

2. A decline in the role of planning for economic life, which can be said to be canceled, for the benefit of large companies.

3. Economic development and technological modernization have become dependent on the US hegemonic policies and its mechanisms in globalization, meaning deepening the dependence of political and economic systems on these mechanisms, especially foreign investments.

4. Spreading extravagant consumption, especially for the commodities produced by the countries of this globalization, especially in the consumption of food commodities such as hamburger, Coca-Cola, programs, films, clothes and entertainment that have a negative impact on social and economic life.

5. Globalization has led to economic and financial crises in America itself, such as the financial crisis in 2008, and the economic crisis in Southeast Asian countries that occurred as a result of financial globalization and the merging of markets that led to more unemployment in those countries ${ }^{(8)}$.

Accordingly, economic globalization is a constructive and deconstructive civilization as well. It has contributed to bringing about economic development and technological modernization for some countries, just as it has negatively contributed to the economic, social, political and cultural life of these countries and others.

It should be noted that this globalization, describing one of its aspects, represents an economic, cultural, social and political challenge for developing countries in particular through the following: 
1. The issue of freedom of international trade, as this freedom constitutes a basic need for various countries to develop their economies, satisfy their economic needs of goods and services, and dispose of the surplus of their products, despite what is said that this freedom is not in the interest of countries.

Developing ${ }^{(9)}$. But it is inevitable to move away from this freedom. With a focus on considering the conditions of developing countries, especially the large scale of unemployment and the great need for investments, and encouraging their products to compete internationally.

2. The issue of global capital movement and foreign direct investment, which represents a way to achieve development, meaning there is no economic development without foreign direct investments in developing countries that lack these investments. It should consider the issue of not influencing its economic decision and not leading to the economic and political influence of investors inside the developing country, that is, it is not a state within a state. And that the capital should go to the basic productive activities of development, such as agriculture and industry, associated with the transfer of technological levels appropriate to the characteristics of the developing country.

3. The issue of the freedom of internal markets, and this issue is the result of the first and second issues, meaning their reflection on the freedom of internal markets in the developing country, especially that among the requirements of those two issues is the spread of the culture of the free market system, further privatization and the removal of economic restrictions on the activities of private economic activity.

\section{THE EFFECTS OF ECONOMIC GlobalizATION ON THE ARAB ECONOMIC INTEGRATION PROJECT AND WAYS TO PROTECT IT}

Various countries of the world have become unable to block their outlets in front of the mechanisms of economic globalization and its negative and positive effects, which were evident in the previous discussion, including the Arab countries that aim to achieve their economic integration project. Therefore, there are positive and negative effects of this globalization.

The positive effects are evident through its role in providing foreign direct investments to Arab economies that lack these investments that lead to achieving development, especially in its integrated economic project, and this means that this globalization can contribute to the development and development of this project.

As for the negative effects of globalization, which constitutes a challenge to the Arab economic integration project, it is evident through the following:

1. This globalization blunts the sovereignty and independent decision of the countries of this project, especially in the abolition of the historical specificity of every nation ${ }^{(10)}$.

2. This globalization constitutes a challenge to the role of Arab nationalism, meaning a challenge to its economic integration project.

3. Imposing an economic dependency on America.
4. This globalization increases the power of the new Middle Eastern project and the role of Israel in achieving its expansion project at the expense of the Arabs.

5. Weakening basic economic activities, especially industry and agriculture, in a way that increases marginal activities and extravagant consumption, meaning encouraging investments that are not economically productive.

\section{Weakening Arab economic security.}

7. The increase in the size of administrative and financial corruption resulting from internal and external causes, and its model is what happened to Iraq after the 2003 invasion and occupation of the United States, whose gateway was the loss and waste of billions of dollars and their disappearance at the time of the American civil ruler (Bremer).

8. The increase in the external indebtedness of some Arab countries in light of this globalization ${ }^{(11)}$.

Faced with these negative effects, it is imperative to define ways to protect the Arab economic integration project from this globalization, through several measures and means, most notably the following:

1. The necessity of establishing economic infrastructure projects between Arab countries, especially neighboring countries such as highways, railways and maritime transport (12)

2. The possibility of reviving old economic projects, establishing a free trade zone, trying to revive the common Arab market ${ }^{(13)}$, establishing joint agricultural and industrial projects between neighboring Arab countries, and developing existing projects such as the Gulf Cooperation Council.

3. Coordination of economic policies among Arab countries, especially those involved in economic integration projects, and attempts to develop joint economic strategies stemming from the national interest of the Arab peoples.

\section{CONCLUSIONS AND RECOMMENDATIONS}

\section{A. Conclusions:}

1. The emergence of economic problems as a result of this globalization despite its positive role in achieving development and modernization in a number of countries, including China, such as the problem of corruption and inflation.

2. European globalization, as a European bloc, had a great role in confronting the negative effects of American globalization, as a result of achieving its economic project, and then European political and cultural projects.

3. The main arm of globalization has led to transcontinental companies and their large investments in other countries, including the developing ones, to the marginalization of small companies and the marginalization of the poor in the countries of the world.

\section{B. Recommendations:}

1. The necessity of establishing agricultural and industrial projects and free zones between the neighboring Arab countries. 
2. It is necessary to deal with this globalization in a way that guarantees the interests of the Arab economies and their integrated project.

3. Encouraging intra-Arab foreign trade.

4. Encouraging investments (Arab - Arab) as an alternative to foreign investments.

5. The necessity of establishing infrastructure projects for the economy, such as railways, highways, and maritime transport between Arab countries, especially the neighboring countries.

6. It is imperative to deal with this globalization in a way that guarantees the interests of the Arab economies and their integrated project, especially in light of the challenge of the new Middle East project.

\section{REFERENCES}

[1] Dr. Abdel-Rahman Yousry, Introduction to International Economics, Egyptian Universities House, Alexandria, 1979, pp. 14-15

[2] Dr. Muhammad Ali Al-Jasem, Basic Rules - International Economy Book Two - Cooperation, Al-Jahiz Publishing House, Baghdad, 1976, p. 216

[3] Burhan Dajani, Through Economic Development in the Arab World, General Secretariat of the General Federation of Chambers of
Commerce, Industry and Agriculture of the Arab Countries, 1992, pp. 304-305

[4] Abdel Moneim Al-Sayed Ali, Arab economic integration and the Middle Eastern economic system - contradiction, overlap and alternatives, Arab Future magazine, Center for Arab Unity Studies, Issue (214), Beirut, 1996, p. 5

[5] Salem Tawfiq al-Najafi, The Middle Eastern Economic Problematic An Arab Vision, Journal of the Arab Future, Center for Arab Unity Studies, No. (209), Beirut, 1996, p. 24

[6] Abdel Moneim Al-Sayed Ali, previous source, p.6

[7] Jalal Amin, Globalization and the State, Arab Future Magazine, Center for Arab Unity Studies, No. (228), Beirut, 1998, p. 24

[8] Dr. Hamid Al-Jumaili, Globalization and the Problem of Sustainable Human Development, Studies in Sustainable Human Development in the Arab World, House of Wisdom, 2000, p. 198

[9] Muhammad al-Atrash, On the Challenges of the Trend Toward Economic Globalization, Arab Future Magazine, Center for Arab Unity Studies, Issue (260), Beirut, 2000, p. 13

[10] Muhammad Abed Al-Jabri, Globalization and Cultural Identity, Journal of the Arab Future, Center for Arab Unity Studies, Issue (228), Beirut, 1998, P14

[11] Dr. Walid Ramez Arbid, Globalization between Culture and Economy, Dar Al-Maha, Beirut, 2013, pg. 64

[12] Prof. Dr. Muhammad Taqah, The Dilemma of Globalization and the Inevitability of Collapse, First Edition, Tigris House, 2018, 2018, pg 64

[13] Prof. Dr . Muhammad Taqah, Economic Globalization, First Edition, Baghdad, 2001, p. 80 